\title{
Callus Formation and Multiplication in Taro
}

\author{
Josue Jack F. Malamug, Susumu Yazawa and Tadashi Asahira \\ Faculty of Agriculture, Kyoto University, Sakyo-ku, Kyoto 606-01
}

\begin{abstract}
Summary
Callus was induced from shoot tip explants of taro (Colocasia esculenta Schott) using modified Nitsch medium containing major elements of Nitsch and minor elements and organic addenda of Ringe and Nitsch with $2 \%$ sucrose, $0.8 \%$ agar and $1 \mathrm{mg} \cdot$ liter $^{-1}$ of 2,4-dichlorophenoxyacetic acid (2,4-D) and 6-benzyladenine (BA), each. The same growth regulators were used in the multiplication of callus. Furthermore, an auxin combination of 2,4-D and NAA at $1 \mathrm{mg} \cdot$ liter $^{-1}$ each have beneficial effects on the multiplication of callus.

By reducing the concentration of $\mathrm{NH}_{4} \mathrm{NO}_{3}$ from $720 \mathrm{mg} \cdot$ liter $^{-1}$ to $200 \mathrm{mg} \cdot \mathrm{liter}^{-1}$, the degree of callus formation and percent of explants forming callus increased. Low level of $\mathrm{NH}_{4} \mathrm{NO}_{3}$ was found to upgrade the formation and growth of callus.

Addition of $10 \%$ coconut water was beneficial to the induction of callus, on the other hand, it was not beneficial to the multiplication of callus but rather promoted root formation. Medium concentration had no significant effect on the formation and growth of callus.
\end{abstract}

\section{Introduction}

Callus of taro, a member of Araceae family, is difficult to induce from various plant parts (10). A report on callus formation from a Japanese cultivar of taro using different explants on a medium supplemented with $10^{-5} \mathrm{M}$ BA and $10^{-6} \mathrm{M}$ NAA showed some encouraging results with the percent of explants. forming callus ranging from 25 to $78 \%(5)$. But at this rate of callus formation modifications of the basal medium should be considered since the rate is still very low to be adapted as a technique for taro callus propagation. Many researchers have tested various types of culture media in inducing taro callus but results are still unsatisfactory in considering an appropriate media, since callus formation appears to be variety dependent (4) and cultivar dependent (8). Linsmaier and Skoog (LS) medium (7) and Murashige and Skoog (MS) medium (12) are the widely used media in inducing taro callus, but usually explants on these media proceed to organogenesis resulting in the formation of shoots or plantlets.

Nitsch medium (13) was used by Geier (3) in the plant regeneration of Anthurium scherzerianum (Schott) of Araceae family, and he observed a sig-

Received for publication 4 July 1991. nificant level of callus formation.

Plant regeneration from tissue and cell cultures is important in achieving rapid clonal multiplication, recovery of pathogen-free plants, preservation of valuable germplasm and induction of chromosomal and genic variation $(6,11,20)$.

Since taro is propagated vegetatively, no breeding program has been established. That is why, present-day cultivars have existed for hundred of years without improvement. New and/or additional variations are indispensable for taro improvement. These variations can be induced in plantlets differentiated in cultured callus.

In this study, an investigation was undertaken in order to develop a model system of callus induction and multiplication of taro using Nitsch medium as the basal medium.

\section{Materials and Methods}

Apical shoots which emerged from taro (Colocasia esculenta) corms were excised and surfacesterilized after removing a few scale leaves. After the sterilization procedure, shoot tip explants were excised under a low-power dissecting microscope and explanted onto the culture medium containing major elements of Nitsch medium (13) and minor elements and organic addenda of Ringe and Nitsch medium (15) with $2 \%$ sucrose and $0.8 \%$ agar. This 
medium was designated as modified Nitsch medium.

The $\mathrm{pH}$ was adjusted to 5.8 with $\mathrm{HCl}$ and $\mathrm{NaOH}$ before adding the agar. The medium was autoclaved at $1.2 \mathrm{~kg} \cdot \mathrm{cm}^{-2}, 120^{\circ} \mathrm{C}$ for $15 \mathrm{~min}$. Plant growth regulators were added before autoclaving. Explants were placed on $20 \mathrm{ml}$ agar medium in test tubes covered with Morton caps. Incubation was normally at $25^{\circ} \pm 3^{\circ} \mathrm{C}$ under dark condition since illumination was found to strongly inhibit the formation and growth of taro callus (8).

For the callus multiplication experiment, each piece of callus was divided to two or three pieces of not less than $3 \mathrm{~mm} \times 3 \mathrm{~mm}$. Necrotic parts were removed, and only the friable part on the base of the explant was used in the experiment. The pieces of callus were transferred to a fresh medium in a $200 \mathrm{ml}$ Erlenmeyer flask. A square of aluminum foil ( 3 sheets) was used to seal the flasks.

The degree of callus formation and the degree of callus multiplication (DCM) were computed based on the average score using 4 level $(0 \sim 3)$ scoring standard. The percent of explants forming roots and shoots was also measured.

\section{Effects of 2,4-D and $B A$ on callus formation}

Shoot tip explants of cv. Egu-imo were placed on the basal medium with various concentrations of 2,4-D and BA, and the degree of callus formation and percent of callusing were observed after 40 days of culture.

\section{Influence of $\mathrm{NH}_{4} \mathrm{NO}_{3}$ concentration on callus for- mation and multiplication}

Shoot tip and callus explants of cv. Egu-imo were used in this experiment. Three types of culture media according to the adjusted $\mathrm{NH}_{4} \mathrm{NO}_{3}$ concentration were used in the experiment: 1) $0 \mathrm{mg} \cdot \mathrm{liter}^{-1}\left(\mathrm{NH}_{4}{ }^{+}=0 \mathrm{mM}, \mathrm{NO}_{3}{ }^{-}=9.40 \mathrm{mM}\right.$, ratio =0), 2) $200 \mathrm{mg} \cdot$ liter $^{-1}\left(\mathrm{NH}_{4}{ }^{+}=2.50 \mathrm{mM}, \mathrm{NO}_{3}{ }^{-}=\right.$ $11.90 \mathrm{mM}$, ratio $=1: 4.8)$, 3) $720 \mathrm{mg} \cdot \mathrm{liter}^{-1}\left(\mathrm{NH}_{4}{ }^{+}\right.$ $=9.00 \mathrm{mM}, \mathrm{NO}_{3}{ }^{-}=18.39 \mathrm{mM}$, ratio $=1: 2.0$ ).

2,4-D and BA were added at $1 \mathrm{mg} \cdot$ liter $^{-1}$ each.

\section{Relationship between the culture medium concen- tration and callus formation}

Three cultivars namely, Egu-imo, Dotare and Takenoko-imo were used in this experiment. $\mathrm{NH}_{4} \mathrm{NO}_{3}$ concentration of the control medium (1X) was adjusted to $200 \mathrm{mg} \cdot$ liter $^{-1}$. The medium con- centration was adjusted into the following strength: 1) $1 / 2 \times$, 2) $1 \times$, 3) $2 \times$. 2,4-D and BA were added at $1 \mathrm{mg} \cdot$ liter $^{-1}$ each.

\section{Effect of coconut water on callus formation and multiplication}

Three cultivars namely, Egu-imo, Dotare and Takenoko-imo were used in this experiment. $\mathrm{NH}_{4} \mathrm{NO}_{3}$ concentration of the culture medium was adjusted to $200 \mathrm{mg} \cdot \mathrm{liter}^{-1}$. Coconut water from immature (green) nuts was used in the experiment. Coconut water was filtered and stored at $-20^{\circ} \mathrm{C}$. The coconut water was added to the medium at $10 \%(\mathrm{~V} / \mathrm{V})$ concentration prior to the $\mathrm{pH}$ adjustment.

\section{Effect of different auxin combinations on the mul- tiplication of callus}

Callus of cv. Egu-imo was transferred on a fresh medium with various combinations of auxins, namely: 2,4-D + naphthalene acetic acid (NAA), 2,4-D + indolebutyric acid (IBA), 2,4-D + indoleacetic acid (IAA), NAA + IBA, NAA + IAA, IBA + IAA.

The auxins were added on the medium at $1 \mathrm{mg} \cdot$ liter $^{-1}$ making a total of $2 \mathrm{mg}$-liter ${ }^{-1}$ of auxin in the medium. $\mathrm{NH}_{4} \mathrm{NO}_{3}$ concentration of the culture medium was adjusted to $200 \mathrm{mg} \cdot$ liter $^{-1}$.

\section{Results}

After 3 weeks of culture, callus initiation was observed from the base of the shoot tip explants. After 60 days of culture, callus that formed from the explants was completely distinguishable. Callus that formed from the explants was of bubble type, a friable callus (Fig. 1A).

Observation through a scanning electron microscope (SEM) showed that the mass of cells was composed of small and large cells and had no epidermal tissue, signifying that the tissue induced in shoot tip culture is a callus and not a shoot primordium (Fig. 1B).

\section{Effects of 2,4-D and $B A$ on callus formation}

Callus formation was observed in all media regardless of 2,4-D and $\mathrm{BA}$ concentrations (Table 1). The highest degree of callus formation and the percent of explants forming callus were recorded at 1.90 and $94 \%$ respectively in the medium with $1 \mathrm{mg} \cdot$ liter $^{-1}$ 2,4-D and BA each. The addition of $2,4-\mathrm{D}$ was beneficial to the formation of callus. 
High level of 2,4-D and BA was detrimental to the formation of callus (Table 1).

\section{Influence of $\mathrm{NH}_{4} \mathrm{NO}_{3}$ concentration on callus for- mation and multiplication}

The degree of callus formation and the percent of explants forming callus were recorded highest in the medium with $200 \mathrm{mg} \cdot$ liter $^{-1} \mathrm{NH}_{4} \mathrm{NO}_{3}$ at 1.40 and $93.3 \%$, respectively. The lowest level of callus formation was measured in the medium con-
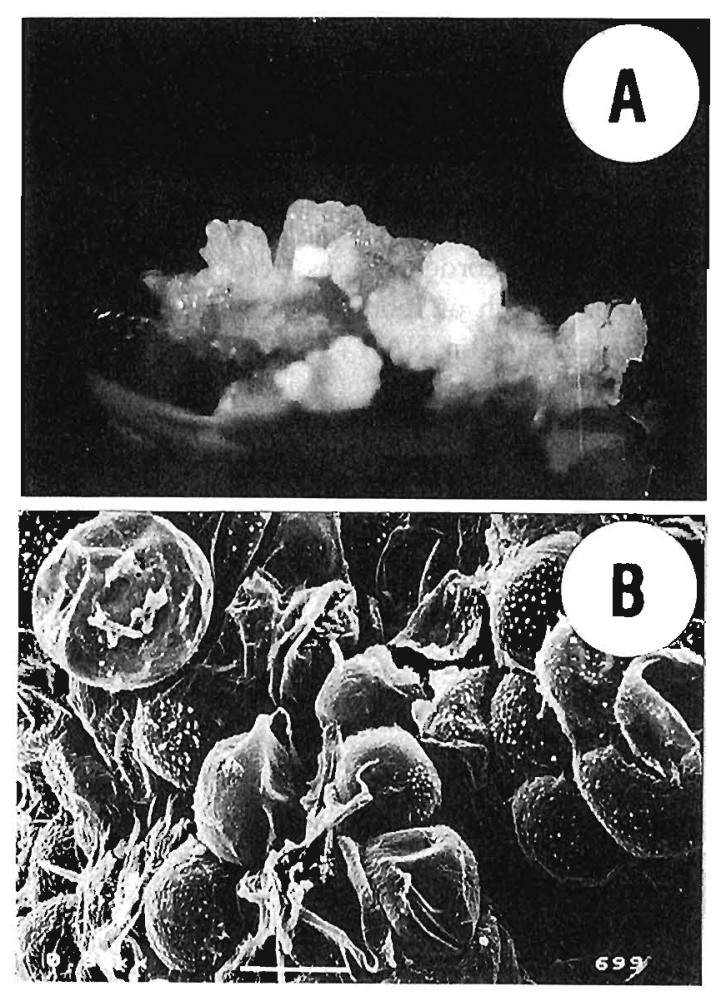

Fig. 1. (A) Taro callus induced from shoot tip explants on a modified Nitsch medium. (B) A taro callus observed from a scanning electron microscope (SEM). taining $720 \mathrm{mg} \cdot$ liter ${ }^{-1} \mathrm{NH}_{4} \mathrm{NO}_{3}$ (Table 2).

The degree of callus multiplication in the subculture was the same on the media with 0 and $200 \mathrm{mg} \cdot$ liter $^{-1} \mathrm{NH}_{4} \mathrm{NO}_{3}$ (Table 3). The degree of callus multiplication on the medium with $720 \mathrm{mg} \cdot \mathrm{liter}{ }^{-1} \mathrm{NH}_{4} \mathrm{NO}_{3}$ was very low, at 0.5 . The percent of explants forming hair root was highest in the medium with $720 \mathrm{mg} \cdot{ }^{-1}$ iter ${ }^{-1} \mathrm{NH}_{4} \mathrm{NO}_{3}$. The percent of explants forming root hairs increases with the concentration of $\mathrm{NH}_{4} \mathrm{NO}_{3}$ (Table 3).

In both experiments, the most number of explants showing browning, signs of necrosis, were observed on the medium not supplemented with $\mathrm{NH}_{4} \mathrm{NO}_{3}$.

\section{Relationship between the culture medium concen- tration and callus formation}

Various morphogenetic responses were observed depending on the different strengths $(1 / 2 \times, 1 \times$, $2 \times$ ) of modified Nitsch medium (Table 4). The degree of callus formation of all media was relatively high ranging from 1.5 to 2.2. Also, the per-

Table 1. Effects of 2,4-D and BA concentrations on callus formation of taro.

\begin{tabular}{|c|c|c|c|c|c|}
\hline \multirow{2}{*}{\multicolumn{2}{|c|}{$\begin{array}{c}\text { Growth regulator } \\
\left(\mathrm{mg} \cdot \text { liter }^{-1}\right)\end{array}$}} & \multirow{3}{*}{$\begin{array}{l}\text { No. of } \\
\text { explants }\end{array}$} & \multirow{3}{*}{$\begin{array}{l}\text { No. of } \\
\text { browning } \\
\text { explants }\end{array}$} & \multicolumn{2}{|c|}{ Callus formation } \\
\hline & & & & \multirow{2}{*}{$\%$} & \multirow{2}{*}{ Degree } \\
\hline $2,4-D$ & $\mathrm{BA}$ & & & & \\
\hline 0.5 & 0 & 25 & 0 & 80 & 1.60 \\
\hline 0 & 0.5 & 25 & 6 & 28 & 0.37 \\
\hline 0.5 & 0.5 & 25 & 0 & 88 & 1.75 \\
\hline 0.5 & 1 & 25 & 1 & 84 & 1.50 \\
\hline 1 & 0.5 & 25 & 2 & 88 & 1.80 \\
\hline 1 & 1 & 25 & 0 & 96 & 1.90 \\
\hline 5 & 5 & 25 & 10 & 40 & 0.67 \\
\hline
\end{tabular}

2 Degree of callus formation was based on the average score computed using 4-level $(0$; no callus formation, 1 ; slight callus formation, 2; moderate callus formation, 3 ; extensive callus formation) scoring standard.

Table 2. Influence of $\mathrm{NH}_{4} \mathrm{NO}_{3}$ concentration on taro callus formation.

\begin{tabular}{|c|c|c|c|c|c|c|}
\hline \multirow{2}{*}{$\begin{array}{c}\mathrm{NH}_{4} \mathrm{NO}_{3} \\
\text { concn } \\
\left(\mathrm{mg} \cdot \text { liter }^{-1}\right)\end{array}$} & \multirow{2}{*}{$\begin{array}{c}\text { No. of } \\
\text { explants }\end{array}$} & \multirow{2}{*}{$\begin{array}{l}\text { No. of } \\
\text { browning } \\
\text { explants }\end{array}$} & \multicolumn{2}{|c|}{ Callus formation } & \multicolumn{2}{|c|}{$\%$ of explants forming } \\
\hline & & & $\%$ & Degree $^{2}$ & Roots & Shoots \\
\hline 0 & 15 & 5 & 60.0 & 1.3 & 40.0 & 6.7 \\
\hline 200 & 15 & 1 & 93.3 & 1.4 & 26.7 & 0 \\
\hline 720 & 15 & 3 & 80.0 & 0.9 & 20.0 & 0 \\
\hline
\end{tabular}

"Refer Table 1. 
cent of explants forming callus was not affected by the concentration of the culture medium.

Differences on the responses among cultivars were observed, but there was no defined relationship between the medium strength and the percent of explants forming callus. Furthermore, the percent of explants forming shoots was not affected by the concentration of the culture medium. The percent of explants forming roots was high in $1 \times$ strength.

\section{Effect of coconut water on callus formation and multiplication}

The degree of callus formation increased with the addition of coconut water (Table 5). The increase in the degree of callus formation with the addition of coconut water hastened the induction of callus from the explants, as the formation of callus on the medium supplemented with coconut water was observed earlier than that on the control medium.

There was no significant effect of coconut water on the percent of explants forming callus.

There was no positive effect of coconut water on the multiplication of callus (Table 6). The addition of coconut water resulted in an enormous growth of root hairs covering the callus. Cultivar Dotare had the highest percentage of rooting at $90.9 \%$.

\section{Effect of different auxin combinations on the mul- tiplication of callus}

A very high degree of callus multiplication was obtained on the media with 2,4-D included on the combinations (2,4-D +NAA, 2,4-D + IBA, 2,4-D + IAA) (Table 7). The degree of callus multiplication recorded ranges from 2.1 to 2.3. The highest degree of callus multiplication at 2.3 was recorded on the medium containing 2,4-D and NAA.

In the media without 2,4-D, the degree of callus multiplication recorded ranges from 1.1 to 1.3 . An enormous growth of roots was observed on these media especially on NAA + IAA with $96 \%$ of the explants forming roots.

Table 3. Influence of $\mathrm{NH}_{4} \mathrm{NO}_{3}$ concentration on the multiplication of taro callus.

\begin{tabular}{|c|c|c|c|c|c|}
\hline \multirow{2}{*}{$\begin{array}{c}\mathrm{NH}_{4} \mathrm{NO}_{3} \\
\text { concn } \\
\left.\text { (mg-liter }{ }^{-1}\right)\end{array}$} & \multirow{2}{*}{$\begin{array}{c}\text { No. of } \\
\text { explants }\end{array}$} & \multirow{2}{*}{$\begin{array}{l}\text { No. of } \\
\text { browning } \\
\text { explants }\end{array}$} & \multicolumn{2}{|c|}{$\%$ of explants forming } & \multirow{2}{*}{$\mathrm{DCM}^{2}$} \\
\hline & & & Roots & Shoots & \\
\hline 0 & 90 & 6 & 3.3 & 0 & 1.5 \\
\hline 200 & 90 & 0 & 7.8 & 0 & 1.5 \\
\hline 720 & 90 & 0 & 16.7 & 0 & 0.5 \\
\hline
\end{tabular}

${ }^{\text {z } D C M}$ - Degree of callus multiplication. The degree of callus multiplication was based on the average score computed using 4-level (0; no growth, 1; slight growth, 2; moderate growth, 3 ; extensive growth) scoring standard.

Table 4. Relationship between the culture medium concentration and taro callus formation.

\begin{tabular}{|c|c|c|c|c|c|c|c|c|}
\hline \multirow{3}{*}{$\begin{array}{l}\text { Cultivar } \\
\text { Egu-imo }\end{array}$} & \multirow{2}{*}{\multicolumn{2}{|c|}{$\begin{array}{l}\text { Medium } \\
\text { concn }\end{array}$}} & \multirow{3}{*}{$\begin{array}{c}\begin{array}{c}\text { No. of } \\
\text { explants }\end{array} \\
20\end{array}$} & \multirow{3}{*}{$\begin{array}{c}\text { No. of } \\
\text { browning } \\
\text { explants }\end{array}$} & \multicolumn{2}{|c|}{ Callus formation } & \multicolumn{2}{|c|}{$\%$ of explants forming } \\
\hline & & & & & \multirow{2}{*}{$\begin{array}{c}\% \\
100\end{array}$} & \multirow{2}{*}{$\begin{array}{c}\text { Degree } \\
1.8\end{array}$} & \multirow{2}{*}{$\frac{\text { Roots }}{10}$} & \multirow{2}{*}{$\begin{array}{c}\text { Shoots } \\
20\end{array}$} \\
\hline & $1 / 2$ & $x$ & & & & & & \\
\hline & 1 & $x$ & 20 & 1 & 95 & 2.2 & 40 & 0 \\
\hline & 2 & $x$ & 20 & 0 & 100 & 1.9 & 0 & 0 \\
\hline \multirow[t]{3}{*}{ Dotare } & $1 / 2$ & $x$ & 20 & 2 & 90 & 2.0 & 0 & 0 \\
\hline & 1 & $x$ & 20 & 0 & 100 & 2.1 & 30 & 0 \\
\hline & 2 & $x$ & 20 & 0 & 100 & 2.1 & 15 & 10 \\
\hline \multirow[t]{3}{*}{ Takenoko-imo } & $1 / 2$ & $x$ & 20 & 0 & 100 & 1.8 & 0 & 0 \\
\hline & 1 & $x$ & 20 & 0 & 100 & 1.5 & 15 & 0 \\
\hline & 2 & $x$ & 20 & 1 & 95 & 2.0 & 0 & 0 \\
\hline
\end{tabular}

Refer Table 1. 
Shoot differentiation was only observed on the medium containing 2,4-D and NAA.

\section{Discussion}

Taro callus was induced in modified Nitsch medium with 2,4-D and BA. Results show that 2,4-D plays a very important role in the formation and multiplication of taro callus. Often, 2,4-D is used alone to initiate callus (2). The use of auxin combinations as a substitute for the usual auxin and cytokinin combination in the multiplication of taro callus was possible.
The many comparative studies of ammonium and nitrate as sources of nitrogen, undertaken prior to work with tissue and organ cultures, have revealed interesting differences between species and have emphasized the influence of environmental factors (19).

The formation and multiplication of taro callus were optimal on the medium with $200 \mathrm{mg} \cdot \mathrm{liter}^{-1}$ $\mathrm{NH}_{4} \mathrm{NO}_{3}$. In the study about the regeneration of Anthurium scherzerianum leaf segments, the $\mathrm{NH}_{4} \mathrm{NO}_{3}$ level had the most significant effect on callus and shoot formation(3). Also, Pierik and

Table 5. Modified Nitsch medium (1969) used for callus induction of different taro cultivars and the effect of coconut water on the formation of callus.

\begin{tabular}{|c|c|c|c|c|c|c|}
\hline \multirow{3}{*}{ Cultivar } & \multicolumn{3}{|c|}{ Without coconut water } & \multicolumn{3}{|c|}{ With $10 \%$ coconut water } \\
\hline & \multirow{2}{*}{$\begin{array}{l}\text { No. of } \\
\text { explants }\end{array}$} & Callus & formation & \multirow{2}{*}{$\begin{array}{l}\text { No. of } \\
\text { explants }\end{array}$} & \multirow{2}{*}{$\frac{\text { Callus }}{\%}$} & \multirow{2}{*}{$\begin{array}{c}\text { formation } \\
\text { Degree }\end{array}$} \\
\hline & & $\%$ & Degree $^{z}$ & & & \\
\hline Egu-imo & 16 & 87.5 & 1.6 & 17 & 88.2 & 2.1 \\
\hline Dotare & 25 & 96.0 & 2.1 & 25 & 96.0 & 2.3 \\
\hline Takenoko-imo & 25 & 92.0 & 1.5 & 25 & 92.0 & 1.9 \\
\hline
\end{tabular}

2 Refer Table 1.

Table 6. Effect of coconut water on the multiplication of taro callus.

\begin{tabular}{|c|c|c|c|c|c|c|c|c|}
\hline \multirow{3}{*}{ Cultivar } & \multicolumn{4}{|c|}{ Without coconut water } & \multicolumn{4}{|c|}{ With $10 \%$ coconut water } \\
\hline & \multirow{2}{*}{$\begin{array}{c}\text { No. of } \\
\text { explants }\end{array}$} & \multicolumn{2}{|c|}{$\%$ explants forming } & \multirow{2}{*}{$\mathrm{DCM}^{2}$} & \multirow{2}{*}{$\begin{array}{l}\text { No. of } \\
\text { explants }\end{array}$} & \multicolumn{2}{|c|}{$\%$ explants forming } & \multirow{2}{*}{$\mathrm{DCM}$} \\
\hline & & Shoots & Roots & & & Shoots & Roots & \\
\hline Egu-imo & 16 & 0 & 43.8 & 1.0 & 15 & 0 & 46.7 & 0.5 \\
\hline Dotare & 16 & 0 & 62.5 & 0.3 & 11 & 0 & 90.9 & 0.5 \\
\hline Takenoko- & & & & & & & & \\
\hline imo & 16 & 0 & 50.0 & 1.0 & 14 & 0 & 42.9 & 1.0 \\
\hline
\end{tabular}

2 Refer Table 3.

Table 7. Effect of different auxin combinations on the multiplication of taro callus.

\begin{tabular}{|c|c|c|c|c|c|c|}
\hline \multirow{2}{*}{$\begin{array}{l}\text { Auxin } \\
\text { combinations }\end{array}$} & \multirow{2}{*}{$\begin{array}{c}\text { No. of } \\
\text { explants }\end{array}$} & \multirow{2}{*}{$\begin{array}{l}\text { No. of } \\
\text { browning } \\
\text { explants }\end{array}$} & \multicolumn{2}{|c|}{$\%$ of explants forming } & \multirow{2}{*}{$\mathrm{DCM}^{z}$} & \multirow{2}{*}{ Remarks } \\
\hline & & & Roots & Shoots & & \\
\hline $2,4-\mathrm{D}+\mathrm{NAA}$ & 25 & 2 & 32.0 & 4.0 & 2.3 & Dark yellow callus \\
\hline $2,4-D+I B A$ & 25 & 1 & 28.0 & 0 & 2.1 & Dark yellow callus \\
\hline $2,4-D+I A A$ & 25 & 4 & 24.0 & 0 & 2.2 & Dark yellow callus \\
\hline $\mathrm{NAA}+\mathrm{IBA}$ & 25 & 3 & 64.0 & 0 & 1.1 & Root elongation \\
\hline $\mathrm{NAA}+\mathrm{IAA}$ & 25 & 0 & 96.0 & 0 & 1.3 & Root elongation \\
\hline$I B A+I A A$ & 25 & 0 & 88.0 & 0 & 1.2 & Root elongation \\
\hline
\end{tabular}

Growth regulators (2,4-D, NAA, IAA, IBA) were supplemented at $1 \mathrm{mg} \cdot \cdot_{\text {liter }}{ }^{-1}$ making a total of $2 \mathrm{mg} \cdot$ liter $^{-1}$ of auxins.

Refer Table 3 
Steegmans (14) recommended callus induction on a medium with half strength of MS macroelements which means $825 \mathrm{mg} \cdot$ liter $^{-1}$ of $\mathrm{NH}_{4} \mathrm{NO}_{3}$.

The adjustment of $\mathrm{NH}_{4} \mathrm{NO}_{3}$ level to $200 \mathrm{mg}$. liter ${ }^{-1}$ resulted in the low ratio of $\mathrm{NH}_{4}-\mathrm{N}$ to $\mathrm{NO}_{3}-\mathrm{N}$ from $\mathrm{KNO}_{3}\left(950 \mathrm{mg} \cdot \mathrm{liter}^{-1}\right.$ ). The beneficial effect of low ammonium/nitrate ratio on the formation of callus was observed in Anthurium scherzerianum (21).

This supports the idea that the beneficial effects of low $\mathrm{NH}_{4} \mathrm{NO}_{3}$ observed in Anthurium, also a member of family Araceae, have the same effects on the formation and multiplication of taro callus.

On the study of Geier (3) on Anthurium scherzerianum, high $\mathrm{NH}_{4} \mathrm{NO}_{3}$ level $\left(720 \mathrm{mg} \cdot 1\right.$ iter $\left.{ }^{-1}\right)$ strongly accelerated root formation. But in our study, the increase of root formation due to high $\mathrm{NH}_{4} \mathrm{NO}_{3}$ was observed only on the callus multiplication experiment. A reverse effect was observed on the case of the callus induction experiment.

Generally, low medium concentration implies low level of available ions which may result to decreased growth of cells. On the other hand, high medium concentration implies a high level of ions or salts which is detrimental to cells due to salt sensitivity. Based on the results of this study, the culture medium concentration used in the experiment had no significant effects on the formation of taro callus.

Organic nutrient sources are effective for the proliferation of plant cells cultured in vitro $(17,18)$. In a liquid Knudson C (1946) medium added with coconut water and adenine, shoot tips of taro formed protocorm-like bodies, and when transferred to solidified MS medium with $10 \%$ coconut water, each explant produced 4 to 8 plantlets from the proliferated base of the shoot tip (10).

Taro callus was formed vigorously from taro shoot tip explants in the modified Nitsch medium supplemented with $2,4-\mathrm{D}, \mathrm{BA}$ and $10 \%$ coconut water. But, multiplication of callus was inhibited when subcultured in the presence of $10 \%$ coconut water. This may be due to the addition of coconut water, implying that whatever is good for callus induction may not be good for callus multiplication. Addition of coconut water seems to induce root differentiation.

A medium for taro callus induction was developed by Abo El-Nil and Zettler. This medium, a revised Schenk and Hildebrandt medium (16) con- taining higher concentrations of $\mathrm{PO}_{4}{ }^{-}, \mathrm{NH}_{4}{ }^{+}$, $\mathrm{Ca}^{++}, \mathrm{Fe}^{+++}, \mathrm{Zn}^{++}$and $\mathrm{B}$, is called $\mathrm{AZ}$ medium (1).

A study using this medium was conducted but the percent of explants forming callus was very low at $56.3 \%$ (9). Furthermore, when coconut water was added to the medium, no callus formation was observed from the shoot tip explants.

The above result implies that the modified Nitsch medium used in this study is the appropriate medium for taro callus induction and multiplication. Also, the technique introduced in this paper can be used in the improvement of taro cultivars through induction of genic or chromosomal variation in vitro.

\section{Literature Cited}

1. Abo El-Nil, M.M. and F.W. Zettler. 1976. Callus initiation and organ differentiation from shoot tip cultures of Colocasia esculenta. Plant Science Letters $6: 401-408$.

2. Evans, D.A., W.R. Sharp and C.E. Flick. 1981. Growth and behavior of cell cultures: embryogenesis and organogenesis. p.45-113. In : I.A. Thorpe (ed.). Plant tissue culture, methods and applications in agriculture. Academic Press, New York.

3. Geier, T. 1986. Factors affecting plant regeneration from leaf segments of Anthurium scherzerianum Schott (Araceae) cultured in vitro. Plant Cell Tiss. Org. Cult. $6: 115-125$.

4. Jackson, G.V.H., E. A. Ball and J. Arditti. 1977. Tissue culture of taro, Colocasia esculenta (L.) Schott. J. Hort. Sci. 52 : 373-382.

5. Kuriyama, T. and K. Oosawa. 1976. Relationship between plant portion and culture medium with callus and plantlet formation in taro. Bulletin of the Vegetable and Ornamental Crops Research Station for Plant Breeding 3: 12-14. (In Japanese).

6. Larkin, P.J. and W.R. Scowcroft. 1981. Somaclonal variation $-A$ novel source of variability from cell cultures for plant improvement. Theor. Appl. Genet. 60 : 197-214.

7. Linsmaier, E.M. and F. Skoog. 1965. Organic growth factor requirements of tobacco tissue cultures. Physiol. Plant. $18:$ 100-127.

8. Malamug, J.J.F. 1987. Induction of genetic mutation through tissue culture in taro. Undergraduate Thesis. Kyoto University, Sakyo-ku, Kyoto. (In Japanese).

9. Malamug, J.J.F. 1989 . Tissue culture studies on taro (Colocasia esculenta (L.) Schott). Masteral Thesis. Kyoto University, Sakyo-ku, Kyoto.

10. Mapes, M.O. and M.J. Cable. 1972 . Mericloning of taro Colocasia esculenta. Hawaii Agricultural Station Journal, Series No. 1694. 
11. Murashige, T. 1974. Plant propagation through tissue culture. Annu. Rev. Plant Physiol. 25: 135-166.

12. Murashige, T. and F. Skoog. 1962. A revised medium for rapid growth and bioassays with tobacco tissue cultures. Physiol. Plant. 15: 473-497.

13. Nitsch, J.P. 1969. Experimental androgenesis in Nicotiana. Phytomorphology 19 : 389-404.

14. Pierik, R.L.M. and H.H.M. Steegmans. 1976. Vegetative propagation of Anthurium scherzerianum Schott through callus cultures. Scientia Hortic. 4:291-292.

15. Ringe, F. and J.P. Nitsch. 1968. Conditions leading to flower formation on excised Begonia fragments cultured in vitro. Plant Cell Physiol. $9: 639-652$.

16. Schenk, R.U. and A.C. Hildebrandt. 1971. Medium and techniques for induction and growth of monocotyledenous and dicotyledonous plant cell cultures. Can. J. Bot. $50: 199-204$.

17. Steward, F.C. 1961. Vistas in plant physiology: Problems on organization, growth and morphogenesis. Can. J. Bot. 39:441-460.

18. Steward, F.C. and H.Y. Mohan Ram. 1961. Determining factors in cell growth: Some implications for morphogenesis in plant. Advanc. Morphogen. 1: 189-265.

19. Street, H.E. and D.E.G. Sheat. 1958. The absorption and availability of nitrate and ammonia. p. 150-161. In: W. Ruhland (ed.). Encyclopedia of plant physiology. Vol. 8. Springer, Berlin.

20. Vasil, V. and I.K. Vasil. 1980. Isolation and culture of cereal protoplasts. Part 2. Embryogenesis and plantlet formation from protoplasts of Pennisetum americanum. Theor. Appl. Genet. 56:97-99.

21. Zens, A and K. Zimmer. 1986. In vitro propagation of Anthurium scherzerianum. Gartenbauwissenschaft $51: 26-31$. (In German).

\title{
サトイモのカルスの形成および增殖 \\ J.J.F. Malamug · 矢澤 進・浅平 端 \\ 京都大学莀学部 606-01 京都市左京区
}

\begin{abstract}
摘要
修正 Nitsch 培地を用いたサトイモの茎頂培荃におい て，カルス形成が認められた. 修正 Nitsch 培地の組成 は Nitsch (1969) 培地の多量要素および Ringe・Nitsch （1968）の微最要素と有機化合物からなる，また，この 培地にショ糖 $2 \%$, 寒天 $0.8 \%, 2,4-\mathrm{D} 1 \mathrm{mg} \cdot \mathrm{liter}^{-1}$ と BA $1 \mathrm{mg} \cdot$ liter $^{-1}$ を添加した。同じ組成の培地は力 ルスの增殖にも有効であった。しかし，BA を加えない $1 \mathrm{mg} \cdot$ liter $^{-1} 2,4$-D および $1 \mathrm{mg} \cdot$ liter $^{-1} \mathrm{NAA} の$ 2 種類のオーキシンの組み合わせでもカルスの增殖に

効果的だった，培地中の $720 \mathrm{mg} \cdot \mathrm{liter}^{-1} \mathrm{NH}_{4} \mathrm{NO}_{3}$ 含最 を200 mg・liter ${ }^{-1} に$ 減らすと, 力ルス形成程度および力 ルス形成率は增加した。低湍度の $\mathrm{NH}_{4} \mathrm{NO}_{3}$ はカルスの 增殖も促進した。

$10 \%(\mathrm{~V} / \mathrm{V})$ の coconut water はカルス形成に有效 であったが，カルス增殖には抑制的な影㗽を及ぼし， 根の形成を促進した，修正 Nitsch 培地の泿度 $(2,1$ および $1 / 2$ 倍)はカルス形成に有意な影響を及ぼさな かった。
\end{abstract}

